3. Рібцун Ю. В. (2020) Розвиток емоційної сфери дітей із порушеннями мовленнєвого розвитку. Освіта осіб з особливими потребами: иляхи розбудови. Вип. 16.

DOI https://doi.org/10.30525/978-9934-588-80-8-1.42

\title{
ЗАСТОСУВАННЯ АЛЬТЕРНАТИВНОЇ І ДОДАТКОВОЇ КОМУНІКАЦІї: ТЕОРЕТИЧНИЙ ОГЛЯД ВІЗУАЛЬНИХ ЗАСОБІВ АДК
}

\author{
Усатенко Г. В. \\ аспірант лабораторії психології політико-правових відносин \\ Інститут соиіальної та політичної психології \\ Національної академії педагогічних наук Украӥни \\ Чайка М. С. \\ аспірант кафедри психокорекційної педагогіки \\ Національний педагогічний університет імені М. П. Драгоманова \\ м. Київ, Украӥна
}

Метою тез доповіді є висвітлення сучасних систем та візуальних засобів альтернативної і додаткової комунікації (далі - АДК) та їх застосування в розвитку мовлення дітей $\mathrm{i}$ дорослих, які мають порушення мовленнєвого та/або інтелектуального розвитку. За даними науковців, кількість людей, які мають мовленнєві порушення, та внаслідок цього утруднення комунікативної діяльності, неухильно збільшується з кожним роком (Bonora, G., Dalai, G., De Rosa, D., Hillary Zisk A., Panunzi, M., Perondi, L., Rönnberg J., Sundqvist A.). Ця тенденція у виявленні порушень навичок комунікації може бути викликана низкою причин: генетичних, медичних, соціальних, психологічних та педагогічних. Слід зазначити, що в суспільстві збільшення відсотка осіб, які мають порушення мовленнєвого розвитку, співпадає зі зростанням показників підвищення якості проведення медичної, психологічної та педагогічної діагностики $[2,4]$.

Особам із порушеннями мовлення та комунікації необхідна систематична підтримка за допомогою засобів альтернативної i додаткової комунікації. В Україні практика застосування АДК лише розвивається, існує нагальна потреба висвітлення інформації та узагальнення досвіду. 
Альтернативна і додаткова комунікація (alternative and augmentative communication), за визначенням Міжнародної спільноти з альтернативної та додаткової комунікації, - це набір інструментів і стратегій, які використовує людина, щоб виконувати щоденні завдання спілкування [1]. Комунікація має різні форми, такі як мовлення, погляд, текст, вираз обличчя, дотик, рухи тіла та жести, жестова мова, символи, малюнки, використання пристроїв для генерації мовлення тощо. Американська дослідниця Phelps зазначає, що АДК включає в себе низку інструментів, технологій і технік втручання, які мають на меті стимулювати та поліпшувати комунікаційну компетентність осіб з утрудненими комунікативними потребами [5].

Спираючись на визначення іноземних та вітчизняних дослідників, АДК можна описати як способи комунікації, що використовуються у процесі спілкування для функціональної підтримки або альтернативи мовленню у осіб з особливими освітніми потребами (ООП), які мають істотні труднощі з відтворенням або розумінням мовлення. АДК може здійснюватися за допомогою жестів, міміки, зображень, фотографій, піктограм, технічних засобів тощо, які допомагають особі з мовленнєвими порушеннями комунікувати 3 оточенням (передавати, сприймати та розуміти інформацію) та сприяють процесу соціальної інтеграції та взаємодії.

Застосування засобів АДК можна умовно розділити на декілька видів, враховуючи мету використання та вид подання матеріалу. Виділяють візуальні засоби АДК, які найчастіше застосовуються в корекційній та абілітаційній роботі щодо подолання труднощів мовленнєвого спілкування дітей та дорослих людей з ООП: знаки, символи, піктограми, жести, схеми, предметні малюнки, сюжетні ілюстрації тощо. Засоби АДК не просто допомагають установити певну асоціацію до предмету або дії, а повністю або частково відтворюють послідовний ланцюжок мовленнєвих i мисленнєвих операцій, що спрямовані на сприйняття та розуміння вербальної інформації. Разом 3 тим використання засобів АДК стимулюе формування власного мовлення, насичує поняття образами та змістом i допомагає створювати послідовність висловлювання у людини 3 порушеннями мовлення або інтелектуального розвитку. Свропейський дослідник Stephen von Tetzchner використовує також терміни «підтримана комунікація» (aided communucation) та «тотальна комунікація» (total communication), таким чином відзначаючи, що АДК може відбуватися будь-яким способом, доступним людині з інвалідністю [6].

Аналізуючи сучасні системи символів, піктограм АДК, можна відзначити особливості роботи 3 різними віковими категоріями. 162 
Наприклад, для дітей раннього та молодшого дошкільного віку найчастіше використовуються великі картки у монохромному оформленні, що позначають реальні предмети або їх контури. Для дітей дошкільного віку найчастіше зустрічаються деталізовані кольорові зображення на картках середнього розміру. Для молодших школярів та підлітків фахівці часто застосовують картки невеликого розміру 3 кольоровими або монохромними символічними зображеннями або знаками. У роботі з дорослими людьми найчастіше застосовують картки середнього або невеликого розміру, кольорові або монохромні, зі схематичними зображеннями реальних предметів або дій, що поєднуються з різними символами [7].

У світі розроблені методики 3 доведеною ефективністю, наприклад американські системи Picture Exchange Communication Symbols (PECS), Picture Communication Symbols (PCS), європейська ARASAAC та інші набори символів, які не є спрощеними, але вони організовані так, щоб подати інформацію доступно, від простого до складного, візуально. Потрібна системна адаптація таких матеріалів до української мови, враховуючи лінгвістичні особливості та сприймання дітей з ООП.

Українська вчена Куценко Т. О. відмічає, що жодна із систем альтернативної і додаткової комунікації не має на меті вилучити вербальне мовлення 3 ужитку. Понад те, розвиток мовленнєвокомунікативних навичок пришвидшується за рахунок використання АДК. Застосування будь-якого способу альтернативної і додаткової комунікації супроводжується мовленням таким чином, що жест або символ ілюструє слово, формуючи в головному мозку міцні зв'язки між стимулами різних модальностей (звукової, зорової, кінестетичної) [8].

Ураховуючи утруднення вербального спілкування у дітей або дорослих людей, що мають тяжкі мовленнєві або інтелектуальні порушення, включаючи порушення емоційно-вольової сфери, засоби АДК виявляють себе як ефективний спосіб налагодити комунікацію, висловити власні почуття та стани. Проте більшість сучасних зарубіжних науковців пропонують використовувати засоби АДК як основний компонент спілкування лише в тих випадках, коли людина не має можливості спілкуватися вербально внаслідок вагомих причин: порушення мовлення внаслідок ураження мовних центрів у центральній нервовій системі, порушення інервації або нетипова будова органів артикуляційного апарату, паралічі, важкі порушення інтелектуальної діяльності або ментального розвитку, порушення формування комунікативних навичок внаслідок виражених розладів спектра аутизму тощо. Для осіб, які мають можливість оволодіти навичками усного мовлення, засоби АДК розглядаються як тимчасовий 
реабілітаційний засіб, що здатен прискорити процес накопичення та генералізації понять і мотивувати до спілкування. Такий підхід значно розширює можливості використання символів, знаків та піктограм у корекційній роботі, адже, спираючись на дані (Bonora, G., Ganz, J. B., Lakin, K. C., Perondi, L., Williams, B.) можна зазначити, що після появи перших вербалізацій та їх співвіднесення з образами та реальними предметам або явищами, значно знижується потреба використання засобів АДК у спілкуванні [2]. Таким чином, можна дійти висновку, що використання засобів АДК не перешкоджає розвитку словесного спілкування, а навпаки, стимулює власні вербалізації.

Наразі в Україні практика АДК недостатньо поширена ані в громадських місцях, ані в освіті. Використання 3 раннього віку посібників, адаптованих АДК, сприятиме соціальній інтеграції людей з інвалідністю, реалізує конституційні права на освіту та працю, що також закріплені у міжнародній Конвенції з захисту прав людей 3 інвалідністю, формуватиме толерантність.

\section{Література:}

1. International society of alternative and augmentative communication https://www.isaac-online.org/english/what-is-aac/

2. Bonora G., Dalai G., De Rosa D., Panunzi M., Perondi L., Rubertelli C. PASS: Picture Augmentative Synsemic System. A new system for AAC habilitative practices, theoretical background. Inmaterial. Diseño, Arte y Sociedad. 2019. Vol. 4, No. 8. P. 33-78.

3. D. McNaughton. The Changing Face of Augmentative and Alternative Communication: Past, Present, and Future Challenges. Augmentative and Alternative Communication. 2012. Vol. 28, No. 4. P. 197-204.

4. Hillary Zisk A., Dalton E. Augmentative and Alternative Communication for Speaking Autistic Adults: Overview and Recommendations. Autism in Adulthood. 2019. Vol. 1, No. 2.

5. Phelps Allison T., «Prevalence and Demographics of Augmentative and Alternative Communication (AAC) Users Birth-21: A Survey of Speech-Language Pathologists Serving Learners with Complex Communication Needs (CCN)» (2019). Open-Access ETDs. 1. https://griffinshare.fontbonne.edu/open-etds/1

6. Stephen von Tetzchner, Kaisa Launonen, Beata Batorowicz, Leila Regina d'Oliveira de Paula Nunes, Cátia Crivelenti de Figueiredo Walter, Judith Oxley, Munique Massaro, Kristine Stadskleiv, Chih-Kang Yang \& Débora Deliberato (2018) Communication aid provision and use among children and adolescents developing aided communication: 164 
an international survey, Augmentative and Alternative Communication, 34:1, 79-91, DOI: 10.1080/07434618.2017.1422019

7. Sundqvist A., Rönnberg J. Advanced Theory of Mind in Children Using Augmentative and Alternative Communication. Communication Disorders Quarterly. Vol. 13. P. 86-97.

8. Куценко Т. О. Використання допоміжної альтернативної комунікації при навчанні дітей 3 розладами аутичного спектра / Т. О. Куценко // Освіта осіб з особливими потребами: шляхи розбудови. - 2013. - Вип. 4(2). - С. 209-218. - Режим доступу: http://nbuv.gov.ua/ UJRN/ooop_2013_4(2)_26. 